\title{
Physicochemical and Microbiological Assessment of Some Sachet Water Produced in Irele, Ondo State, Nigeria
}

\author{
Sunday Adewale Akintelu 1,3*:D , Femi Adekunle Folorunso 2(D), Abel Kolawole Oyebamiji 3,4(D), \\ Akinshola Olabamiji Akinola ${ }^{3}$, Ademola Tokunbo Adetunji ${ }^{3}$, Seyifunmi Charles Olugbeko ${ }^{5}$ (D), Aderonke \\ Similoluwa Folorunso 6,*iD \\ 1 School of Chemistry and Chemical Engineering, Beijing Institute of Technology, Beijing, China \\ 2 Department of Anatomy, Osun State University, Osogbo, Nigeria \\ 3 Department of Pure and Applied Chemistry, Ladoke Akintola University of Technology, PMB 4000 Ogbomoso, Nigeria \\ 4 Department of Basic Sciences, Adeleke University, P.M.B. 250, Ede, Osun State, Nigeria \\ 5 Department of Agricultural Economics, Ladoke Akintola University of Technology, Ogbomoso, Nigeria \\ 6 Department of Chemistry, Louisiana State University, Louisiana, USA \\ * Correspondence: folorunsoaderonkesimi@gmail.com (A.S.F.); akintelusundayadewale@ gmail.com (S.A.A.);

Received: 19.02.2021; Revised: 15.04.2021; Accepted: 22.04.2021; Published: 9.05.2021

\begin{abstract}
This study presents the result obtained from the quality assessment of some sachet water produced in Irele, Ondo State, Nigeria. Eight different brands of sachet water certified by the National Agency for Food and Drug Administration and Control (NAFDAC) representing the western, northern, eastern, central and southern part of Irele were obtained, their physicochemical characteristics and microbiological parameters were investigated using standard analytical procedures to determine the level of agreement with World Health Organization (WHO) and Nigerian Industrial Standard (NIS) requirements for drinking water. The results from the Physico-chemical characteristics temperature, electrical conductivity, $\mathrm{pH}$, total dissolved solids, total hardness, total alkalinity, nitrate and chloride were in the range of $6.2-27.0{ }^{\circ} \mathrm{C}, 77.2-142.3 \mu \mathrm{S} / \mathrm{cm}, 7.40-7.60,47.7-99.5 \mathrm{mg} / \mathrm{L}, 11.3-51.3 \mathrm{mg} / \mathrm{L}$, $13.20-70.0 \mathrm{mg} / \mathrm{L}, 0.8$ to $2.5 \mathrm{mg} / \mathrm{L}$ and $0.01-0.02 \mathrm{mg} / \mathrm{L}$ respectively. The concentrations of iron, copper and manganese were in the range of $0.01-0.02 \mathrm{mg} / \mathrm{L}, 0.13-0.18 \mathrm{mg} / \mathrm{L}$ and $0.01-0.6 \mathrm{mg} / \mathrm{L}$. The concentrations of cadmium, mercury, lead, and arsenic were not detected in the sachet water studied except in sample $\mathrm{H}$ were their concentrations were $0.003,0.001,0.01$, and $0.01 \mathrm{mg} / \mathrm{L}$, respectively. The microbial quality of the studied sachet water was within the WHO recommended standard. All the studied parameters have their values within the recommended limit set by WHO except for sample $\mathrm{H}$ with a manganese concentration above the set standard. There is a need for NAFDAC and other water monitoring agencies to focus on promoting the safety of drinking water, particularly sachet water. The Sources of water, production processes, and environment should be inspected regularly by monitory agencies to certify that there is no deviation from recommended standards.
\end{abstract}

Keywords: Sachet water; physicochemical characteristics; microbiological parameters.

(C) 2021 by the authors. This article is an open-access article distributed under the terms and conditions of the Creative Commons Attribution (CC BY) license (https://creativecommons.org/licenses/by/4.0/).

\section{Introduction}

The inadequate supply of water by the Nigerian government has given rise to private individuals' participation in the production of drinking water such as bottle and sachet water [1]. The production and sales of sachet water known to be a safe and instant means of quenching public thirst have significantly helped overcome the insecurity associated with household 
drinking water supply [2]. Sachet water is not pure or sterilized; therefore, it might contain some impurities and infectious microorganisms.

Contamination of water is the major challenge with most of the sachet water, which depend on the source of water, method of treatment, materials used for packaging, nature of disinfectant, purity of the processing factory, and neatness of workers in the section where the water is dispensed into packaging materials and closure [3,4]. Prolonged sachet water storage can increase bacteria counts above the recommended limit, making such sachet water harmful to humans. Bacterial counts are sensitive, practical parameters used in estimating the efficiency of water treatment [5].

Following the recommended good manufacturing and automated process guidelines set by world health organization (WHO) and NAFDAC help eliminate or reduce the contaminant level of sachet water from all the manufacturers, thereby reducing the health challenges associated with bad drinking water in Nigeria. Poor purification techniques and containers in which water is kept after treatment allow impurities from raw water to persist in sachet water [6]. The environments and conditions in which most packaged water is produced and stored face numerous uncertainties [7].

Diseases related to water have been largely reduced in developed countries globally, but this remains a major concern in most developing countries like Nigeria. Fecal contamination of water remains one of the major water pollutants. Pathogens in human and animal feces ultimately find their way into the water supply through improper sewage treatment, increasing the infectious dose and disease-causing water capacity [8].

Cholera is a water-borne disease caused by pathogenic microorganisms directly transmitted to humans when contaminated water is consumed [9]. Cholera has been reported to be an endemic disease in some parts of Nigeria. In 1991, above 16,000 people died worldwide from cholera infection. Improved water treatment can reduce the death rate arising from cholera. Reports from the literature have shown that eliminating or reducing water-borne diseases such as diarrhea, sleeping sickness, and guinea worm infestation is minimal when clean water is provided [10]. To regulate the menace of contaminated sachet water in Nigeria, NAFDAC has declared a nationwide ban on sachet water that does not meet the speculated standard [11]. Poor monitoring team or organization on water quality couple with bribing and corruption has watered down the effectiveness of this ban, thereby making the safety of sachet water uncertain. This study, therefore, intends to estimate the quality of sachet water produce in Irele Local government in Ondo state through physical examination and microbial assessment of the selected sachet water.

\section{Materials and Methods}

\subsection{Description of the study area.}

Irele is a local government in the southwest region of Nigeria. Irele is an agricultural center of Ondo State where crops such as yams, cassava, palm oil, palm kernels, and kola nuts are produced. It is also known for its Bitumen. Irele has an area of 963 square kilometers (372 sq $\mathrm{mi}$ ) and had a population of 145,166 at the 2006 census. Its geographical coordinates are $6^{\circ}$ $29^{\prime} 0^{\prime \prime}$ North, 4${ }^{\circ} 52^{\prime} 0^{\prime \prime}$ East. The geographical location of the sachet water factories was presented in Figure 1. 


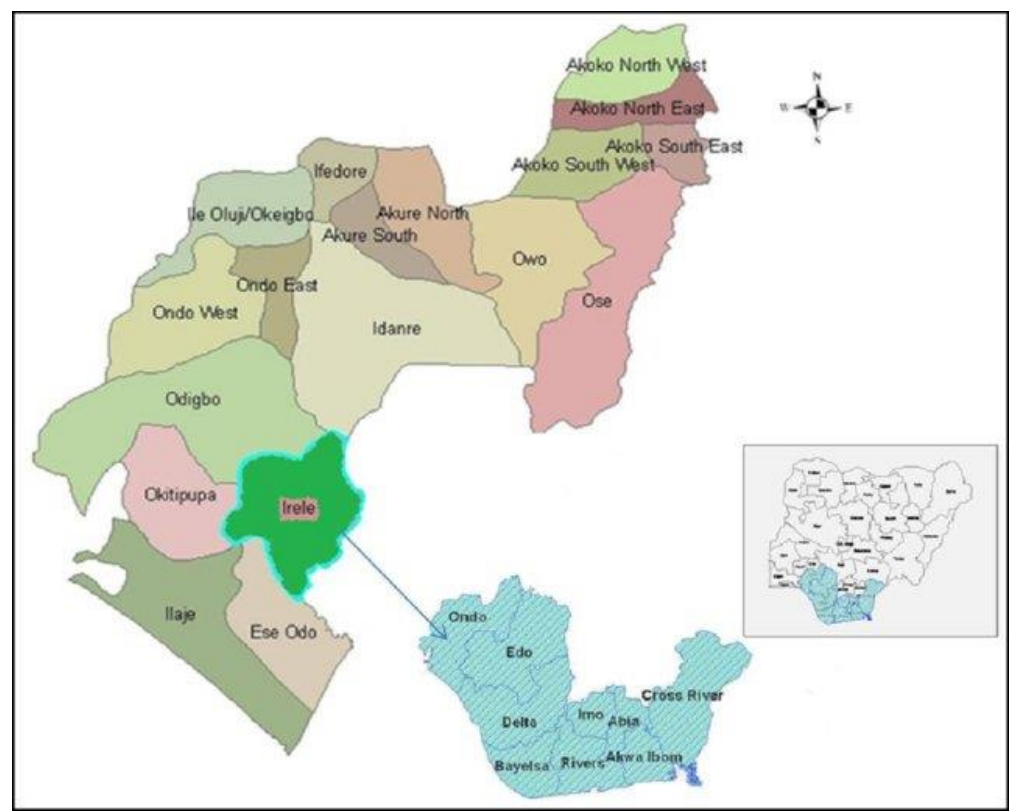

Figure 1. The map of Ondo State showing Irele Local Government Area.

\subsection{Sample collection.}

Eight different brands of 1-liter sachet water samples certified by NAFDAC were obtained. The samples were properly coded, as represented in Table 1. Two bags of each brand of sachet water enclosing twenty sachets were purchased within 24 hours of production and taken to the laboratory for analysis.

Table 1. Samples of water collected.

\begin{tabular}{l|l|l} 
Samples & Sources & NAFDAC NO \\
\hline A & Hakuna Sachet water & C1-6561L \\
\hline B & D-touch Sachet water & A1-3005L \\
\hline C & Top Class Sachet water & C1-9989L \\
\hline D & Ibu Omo Sachet water & C1-8053L \\
\hline E & Morykab Sachet water & A1-1467L \\
\hline F & Fayett Sachet water & A1-6488L \\
\hline G & Divine Grace Sachet water & A1-0242L \\
\hline H & Aquarel Sachet water & C1-1422L
\end{tabular}

2.3. Water quality analyses.

2.3.1. Determination of temperature values.

The temperature was determined with the use of a thermometer and conical flask. The sample was transferred into a beaker. The thermometer's electrode was inserted into the sample, and the reading from the thermometer was recorded in centigrade.

\subsubsection{Determination of electrical conductivity (E.C) values.}

The electrode was properly wetted and then plugged into the conductivity meter before inserted into the beaker containing distilled water. The conductivity meter was then switched on. The zero error was regulated before the electrode was inserted into the beaker containing the sample. The reading was noted after it has stabilized. 
2.3.3. Determination of total dissolved solids (T.D.S) values.

The total dissolved solid values were estimated via calculation from the data obtained from electrical conductivity using the relationship between electrical conductivity and total dissolved solids.

$$
\text { T.D.S= Electrical Conductivity Value x } 0.56
$$

\subsubsection{Determination of total alkalinity values.}

$100 \mathrm{ml}$ of the sample was transferred into a $250 \mathrm{~mL}$ Erlenmeyer flask. Few drops of methyl orange indicator solution were added. The solution turned yellow. The solution was then titrated against $0.02 \mathrm{~N}$ of $\mathrm{H}_{2} \mathrm{SO}_{4}$ until a permanent reddish color appeared. The volume of $0.02 \mathrm{~N} \mathrm{H}_{2} \mathrm{SO}_{4}$ solution used was recorded [12].

$$
\mathrm{Mg} / \mathrm{lCaCO} 3=\frac{(\mathrm{N} \times \mathrm{T} \times 50000)}{\text { Volume of sample used }}
$$

where $\mathrm{N}=$ Normality of Acid and $\mathrm{T}=$ Titration Value

\subsubsection{Determination of total hardness values.}

$100 \mathrm{ml}$ of the sample was measured and transferred into a $250 \mathrm{~mL}$ Erlenmeyer flash. 2 $\mathrm{mL}$ of ammonia buffer solution was added with two drops of Erichrome black $\mathrm{T}$ indicator solution. The solution turns pink. The titration of the solution against standardized $0.01 \mathrm{~N}$ EDTA solution continued until the pink color changes to purple. The volume of EDTA used was documented [13].

$$
\mathrm{Mg} / \mathrm{lCaCO} 3=\frac{(\mathrm{A} \times \mathrm{B} \times 1000)}{\text { Volume of sample used }}
$$

where $\mathrm{A}=$ Titration Value and $\mathrm{B}=1.0$

\subsubsection{Determination of chloride values}

$100 \mathrm{ml}$ of each water sample was transferred into a rinsed $250 \mathrm{~mL}$ conical flask. $1 \mathrm{~mL}$ of potassium chromate indicator was added to the solution, which showed a yellow coloration. The solution was titrated against $0.0141 \mathrm{~N}$ of $\mathrm{AgNO}_{3}$ solution to obtain a reddish-brown coloration. The volume of the $\mathrm{AgNO}_{3}$ solution used was recorded at an endpoint.

$$
\mathrm{Mg} / \mathrm{lCl}=\frac{(\mathrm{N} \times \mathrm{T} \times 35450)}{\text { Volume of sample used }}
$$

where $\mathrm{T}=$ Titre value and $\mathrm{N}=$ Normality of $\mathrm{AgNO}_{3}$

\subsubsection{Determination of $\mathrm{pH}$ values}

The electrode of the $\mathrm{pH}$ meter was properly rinsed with distilled water. The $\mathrm{pH}$ meter was then switched on and was standardized. The $\mathrm{pH}$ meter electrode was then gently inserted into the buffer solution and was allowed to stabilize. The $\mathrm{pH}$ meter reading indicated 4.0. The procedure was repeated using a buffer solution with a $\mathrm{pH}$ of 9.0. The beaker containing buffer solution was then replaced with the beaker containing the samples, and the electrode was then inserted into it. The readings on the $\mathrm{pH}$ meter were recorded. 


\subsubsection{Determination of nitrate values.}

The water sample's flocculation with $0.2 \mathrm{~g}$ mercury (II) chloride crystal was done to remove interfering organic and metallic substances. $50 \% \mathrm{NaOH}$ was added to adjust the $\mathrm{pH}$ to 11 with $\mathrm{NaOH}$. The solution was filtered. $2 \mathrm{~mL}$ of the filtrate was transferred into a $50 \mathrm{~mL}$ evaporating dish, $1 \mathrm{~mL}$ of $1 \%$ sodium salicylate solution was added, and the solution was evaporated to dryness in an oven at $105^{\circ} \mathrm{C}$. The residue obtained was removed, cooled, and 2 $\mathrm{mL}$ concentrated $\mathrm{H}_{2} \mathrm{SO}_{4}$ was added with proper swirling. $15 \mathrm{~mL}$ distilled water free from nitrate was added into the sample residue, and $15 \mathrm{~mL}$ sodium-hydroxide-potassium sodium tartrate solution was pipetted into the solution. Yellow coloration was observed. A blank sample was prepared with the same procedure, and the absorbance on a UV/Visible Spectrophotometer was $420 \mathrm{~nm}$. Nitrate values were determined from the calibration curve by extrapolation.

\subsubsection{Determination of heavy metals.}

The water sample was digested with concentrated nitric acid $\mathrm{HNO}_{3}$ and the concentration of iron, copper, manganese, cadmium, mercury and arsenic present in the water samples were determined with the use of an atomic absorption spectrophotometer.

\subsubsection{Microbiological analyses.}

The total viable count and total coliform count as indices were used to determine the microbiological quality of the water samples. Pour plate method was used for the determination of the total viable count. $0.1 \mathrm{ml}$ of the ten-fold dilution of the water sample prepared was poured on the nutrient agar plates and incubated at $37^{\circ} \mathrm{C}$ for $24 \mathrm{~h}$. The plates were examined for growth after incubation and developed colonies counted using a digital colony counter (Gallenkamp, England). The total coliform counts of the samples were evaluated by plating presumptive positive samples on Mac Conkey.

\section{Results and Discussion}

\subsection{Physiochemical characteristics of water samples.}

Table 2. Physicochemical Characteristics and Microbiological Analysis of Selected Sachet Water PHYSICOCHEMICAL CHARACTERISTICS ANALYSIS

\begin{tabular}{|c|c|c|c|c|c|c|c|c|c|c|}
\hline & & & & & & & & & \\
\hline PARAMETERS & $\mathrm{A}$ & $\mathrm{B}$ & $\mathrm{C}$ & $\mathrm{D}$ & $\mathrm{E}$ & $\mathrm{F}$ & $\mathrm{G}$ & $\mathrm{H}$ & NIS & WHO \\
\hline Temperature ${ }^{0} \mathrm{C}$ & 27 & 27 & 6.2 & 26 & 26 & 24.5 & 27 & 25.8 & Ambient & 28 \\
\hline $\begin{array}{l}\text { Electrical } \\
\text { Conductivity, us/cm }\end{array}$ & 98.2 & 109.3 & 77.2 & 109.3 & 96.8 & 128.1 & 142.3 & 138 & - & 1000 \\
\hline $\mathrm{pH}$ & 7.5 & 7.5 & 7.5 & 7.4 & 7.6 & 7.6 & 7.6 & 7.6 & $6.5-8.5$ & $6.5-8.5$ \\
\hline TDS mg/L & 51.3 & 53.5 & 50.1 & 56.2 & 47.7 & 82.7 & 69.5 & 99.5 & 500 & 500 \\
\hline Total hardness, mg/L & 50 & 49.7 & 50.1 & 51.3 & 38.5 & 25.3 & 20.9 & 11.3 & - & $100-200$ \\
\hline $\begin{array}{l}\text { Total alkalinity, } \\
\mathrm{mg} / \mathrm{L}\end{array}$ & 32.4 & 35.6 & 30 & 70 & 67 & 74.1 & 11.8 & 13.2 & - & 100 \\
\hline Nitrate $\mathrm{mg} / \mathrm{L}$ & 1.5 & 2.5 & 2.5 & 0.8 & 1.5 & 2.5 & 0.8 & 1.6 & 50 & 50 \\
\hline Chloride $\mathrm{mg} / \mathrm{L}$ & 0.01 & 0.02 & 0.02 & ND & 0.02 & 0.01 & 0.02 & 0.01 & 250 & 250 \\
\hline Iron $\mathrm{mg} / \mathrm{L}$ & 0.02 & 0.02 & 0.02 & 0.02 & 0.01 & ND & 0.01 & ND & 0.3 & 0.3 \\
\hline Copper mg/L & 0.12 & 0.07 & 0.04 & 0.18 & 0.12 & 0.03 & 0.07 & 0.04 & 0.2 & 0.2 \\
\hline Manganese $\mathrm{mg} / \mathrm{L}$ & 0.01 & 0.02 & 0.03 & 0.01 & 0.6 & 0.01 & 0.02 & 0.02 & 0.2 & 0.2 \\
\hline Cadmium mg/L & ND & ND & ND & ND & ND & ND & ND & $\begin{array}{l}0.00 \\
3 \\
\end{array}$ & 0.003 & 0.003 \\
\hline Mercury mg/L & ND & ND & ND & ND & ND & ND & ND & $\begin{array}{l}0.00 \\
1\end{array}$ & 0.001 & 0.002 \\
\hline Lead mg/L & ND & ND & ND & ND & ND & ND & ND & 0.01 & 0.01 & 0.01 \\
\hline Arsenic $\mathrm{mg} / \mathrm{L}$ & ND & ND & ND & ND & ND & ND & ND & 0.01 & 0.01 & 0.05 \\
\hline
\end{tabular}




\begin{tabular}{l|l|l|l|l|l|l|l|l|l|l}
\hline \multicolumn{9}{c}{ PHYSICOCHEMICAL CHARACTERISTICS ANALYSIS } & $\begin{array}{l}\text { PERMISSIBLE } \\
\text { LIMIT }\end{array}$ \\
\hline $\begin{array}{l}\text { Coliform count } \\
\text { MPN/100mL }\end{array}$ & 0 & 0 & 0 & 0 & 0 & 0 & 0 & 0 & 10 & 10 \\
\hline E,Coli cfu/mL & ND & ND & ND & 0 & 0 & 0 & 0 & 0 & 0.0 & 0.0 \\
\hline $\begin{array}{l}\text { Streplococcus } \\
\text { faecalis cfu/mL }\end{array}$ & ND & ND & ND & ND & ND & ND & ND & ND & 0.0 & 0.0 \\
\hline Yeast/Mould cfu/mL & ND & ND & ND & ND & ND & ND & ND & ND & - & - \\
\hline $\begin{array}{l}\text { Clostridum welchi } \\
\text { ND }\end{array}$ & NIS = Nigerian Industrial Standard and ND = Not Detected & ND & ND & ND & ND & ND & ND & 0.0 & 0.0 \\
\end{tabular}

\subsubsection{Temperature determination.}

Temperature is used to determine the average thermal energy of a substance. The samples' temperatures in this study ranged from 6.2 to $27.0^{\circ} \mathrm{C}$ (Table 2). The values recorded for temperature were below the maximum recommended standard $\left(28^{\circ} \mathrm{C}\right)$ set by $(\mathrm{WHO})$. The result obtained was in line with previous studies [13,14].

\subsubsection{Electrical conductivity determination.}

All the samples' electrical conductivity was in the range of $77.2-142.3 \mu \mathrm{S} / \mathrm{cm}$ as indicated in Table 2: Highest electrical conductivity was found in sample G while the lowest value was observed in sample C. Water's ability to conduct electricity depends on the total concentration of ionized substances in water, temperature of the water, types of dissolved substances, and ionic strength of the water [15]. This suggests that the samples contained some dissolved ions. The electrical conductivity in this study is higher than that reported by [16]. However, the electrical conductivity was in the range of the standard recommended by WHO for drinking water.

\subsection{3. $\mathrm{pH}$ determination.}

The sachet water samples had $\mathrm{pH}$ values in the range of 7.40 -7.60, as showed in Table 2. $\mathrm{pH}$ is an important operational parameter for estimating the efficacy of chlorination and coagulation, $\mathrm{pH}$ values above 8.0 signify a progressive decrease in efficiency of the chlorine disinfection process. Corrosion of metallic water receptacles may occur at $\mathrm{pH}$ values lesser than 7.0, capable of releasing metals into the water. The toxicity of water with respect to metals majorly dependents on the solubility and types of ions present in them [12]. All the samples analyzed had their $\mathrm{pH}$ values within the range of 6.5 to 8.5 recommended by the World Health Organization (WHO).

\subsubsection{Total dissolved solid parameter.}

Total dissolved solid ranged from 47.7 in sample $\mathrm{E}$ to $99.5 \mathrm{mg} / \mathrm{L}$ in sample $\mathrm{H}$ as represented in Table 2. However, TDS of all the water samples were within WHO and Nigerian Industrial Standard (NIS) standards (500 mg/L). The taste of drinking water is adversely affected when total dissolved solids exceed $500 \mathrm{mg} / \mathrm{L}$ and may make water unsafe for drinking. This signifies that the taste of the samples studied is not adversely affected. This study's TDS values were observed to be higher than the values reported by $[17,18]$.

\subsubsection{Total hardness parameter.}

The obtained total hardness concentrations were between 11.3 and $51.3 \mathrm{mg} / \mathrm{L}$ during the investigation. Sample H has the lowest value of $11.3 \mathrm{mg} / \mathrm{L}$, while sample D had the highest 
total hardness value. The high value of hardness in sample D may be accredited to calcium and magnesium deposits, mainly found in minerals. The total hardness of the sachet water samples conformed to WHO standard. Hard water helps form strong bones and teeth because of high calcium concentration and could also help reduce the dangers of heart diseases. The total hardness of drinking water must be above $8.4 \mathrm{mg} / \mathrm{L}$. The concentration of total hardness above $200 \mathrm{mg} / \mathrm{L}$ could cause scale deposition in the distribution system. This indicates that the consumption of these water samples could enhance bones and teeth formation with less possibility of scaling in storage devices. The concentrations of total hardness of the water in this study were similar to the result reported by [15] on the determination of shelf life of some sachet water in Ogbomoso, Oyo state Nigeria.

\subsubsection{Total alkalinity parameter.}

The concentrations of alkalinity were in the range of 13.20 to $70.0 \mathrm{mg} / \mathrm{L}$. These values were within the WHO specifications $(100 \mathrm{mg} / \mathrm{L})$ for drinking and recreational purposes such as swimming pools. The total alkalinity of water is expressed as the acid-neutralizing ability of water, and it is influenced carbonate, bicarbonate, and hydroxide they contained. The result compares well with the studies of [19] on portability assessment of some bottled water in Abeokuta, Nigeria

\subsubsection{Nitrate concentration.}

Nitrate concentrations were very low in all the brands of sachet water. It ranges from 0.8 to $2.5 \mathrm{mg} / \mathrm{L}$, as presented in Table 2 . The concentrations of nitrate in the water samples fell within WHO permissible standard $(50 \mathrm{mg} / \mathrm{L})$ for drinking water [20]. Intake of water with a high concentration of nitrate above permissible standard was reported to cause health disease called methemoglobinemia (cyanosis, bluish mucous membranes, digestive and respiratory problems) in infants. This suggests that the use of this water might not result in any of the aforementioned health challenges.

\subsubsection{Chloride concentration.}

Chloride ion concentrations varied from $0.01 \mathrm{mg} / \mathrm{L}$ in samples $\mathrm{A}, \mathrm{F}$, and $\mathrm{H}$ to $0.02 \mathrm{mg} / \mathrm{L}$ in samples B, C, E, and $\mathrm{G} \mathrm{mg/L}$, but the chloride ion concentration in sample $\mathrm{D}$ was below the detection limit, as shown in Table 2. In this study, the chloride ion concentrations were within the WHO and NIS maximum permissible concentration of $250 \mathrm{mg} / \mathrm{L}$ for drinking water. This indicates that the water is good for drinking and the taste is not affected. Findings have shown that no adverse health effects on humans have been reported from water consumption with higher chloride concentrations [2]. Notwithstanding, higher concentrations of chloride ions in drinking water can affect the taste. The concentrations observed in this study were lower than 0.31-3.03 mg/L reported for Warri and Abraka sachet water in Nigeria [2] and 5.05-18.97 mg/L for sachet water produced in Ghana [21].

\subsection{Metals analysis of sachet water samples.}

\subsubsection{Iron concentrations.}

The estimated concentrations of iron were, for sample E $0.01 \mathrm{mg} / \mathrm{L}$, and for $\mathrm{G} 0.02$ $\mathrm{mg} / \mathrm{L}$. The concentrations of iron in samples $\mathrm{F}$ and $\mathrm{H}$ were below the detection limit, as 
represented in Table 2. Iron is an essential element that helps in the transportation of oxygen in the blood [20]. Concentrations of iron in all the samples were within the WHO and NIS permissible limit for drinking water $(0.3 \mathrm{mg} / \mathrm{L})$. This confirmed that these water samples are properly treated and may not cause detrimental health effects. Nevertheless, high concentrations of iron could have an impact on the acceptability of drinking water. Therefore, adequate priority must be ensured during drinking water processing.

\subsubsection{Copper ion concentrations.}

The lowest concentration of copper ion was $0.13 \mathrm{mg} / \mathrm{L}$ in sample $\mathrm{F}$ and was at the peak in sample D $0.18 \mathrm{mg} / \mathrm{L}$, as showed in Table 2 . The WHO and NIS recommended concentration of copper in drinking water was $2.0 \mathrm{mg} / \mathrm{L}$. All sachet water samples had copper concentrations below WHO and NIS stipulation. Higher concentrations of copper are regarded undesirable in drinking water because they might cause gastrointestinal disorder by prolonging intake [22]. This shows that this sachet water could not induce gastrointestinal disorder. However, the documented concentrations of copper were lower than $0.99-1.40 \mathrm{mg} / \mathrm{L}$ observed from the research of [18] on a qualitative assessment of sachet sold in Bauchi, Nigeria.

\subsubsection{Manganese concentrations.}

The lowest concentration of manganese was detected in samples A, D and F, while the highest concentration was found in sample $\mathrm{E}$ as represented in Table 2. These concentrations were in the set range of WHO and NIS for drinking water except in sample E with a concentration higher than $0.20 \mathrm{mg} / \mathrm{L}$. High concentrations of manganese affect the taste of water and enhance the growth of bacteria. High concentrations of manganese above recommended standard have also been reported to cause diseases such as lethargy, irritability, headache, sleeplessness, and leg weakness. Among the studied water samples, the consumption of sample $\mathrm{E}$ without further treatment might induce any of the mentioned health challenges.

The concentrations of cadmium, mercury, lead and arsenic were below the detection limit in the sachet water studied except in sample $\mathrm{H}$ were their concentrations were 0.003 , $0.001,0.01$ and $0.01 \mathrm{mg} / \mathrm{L}$, respectively, as showed in Table 2. However, cadmium, mercury, lead, and arsenic concentrations were lower than WHO and NIS maximum limit for drinking water. This suggests that the presence of these metals in the water samples would not affect its quality as drinking water.

\subsection{Microbiological analysis of sachet water samples.}

Coliform count and E. coli were observed to be $0.0 \mathrm{MPN} / 100 \mathrm{~mL}$ and $0.0 \mathrm{cfu} / \mathrm{mL}$, respectively in all the samples except in samples A, B and C where E. coli were absent. Streplococcus faecalis, Yeast and Clostridum welchi were not detected, as represented in Table 2. The total coliform and E. coli counts were within the WHO recommended quality for drinking water. The absence of E coli, Coliform, Streplococcus faecalis, Yeast and Clostridum welchi indicate that the water samples are not contaminated with microbes and provides evidence of a proper treatment process. Microbial contamination of water by fecal coliforms has been ascribed to poor hygienic conditions and improper pipeline maintenance $[23,24]$.

Water contaminated by fecal coliforms is a prospective path of transmission of infectious pathogens, resulting in public health issues [24]. This suggested that the use of any of the sachet water might not harm the public. Our finding revealed that these sachet water are 
good and safe for drinking compares to some sachet water produced in Maiduguri, Nigeria and Dhaka, Bangladesh judging from E. coli and other fecal coliforms count reported by [25, 26]. However, the microbial quality of these water samples was similar to previous investigations in Nigeria by [27] and Ghana by [28].

\section{Conclusions}

The results of this study showed that the physicochemical and microbiological parameters of the sachet water studied were within WHO and NIS standards except for sample $\mathrm{H}$ with an elevated concentration of manganese. The study suggested that some of the packaged water produced in Irele require further treatment before distribution and sale. Therefore, it is recommended that regulatory agencies for sachet water routinely monitor and improve the evaluation process of sachet water to ascertain the production of quality water for drinking purpose as this could help prevent some infectious diseases associated with poor drinking water.

\section{Funding}

This research received no external funding.

\section{Acknowledgments}

The authors would like to thank the administrations of their respective institutions for their support and encouragement during this study. The authors would also like to thank the following water companies, namely Hakuna Sachet water, D-touch Sachet water, Top Class Sachet water, Ibu Omo Sachet water, Morykab Sachet water, Fayett Sachet water, Divine Grace Sachet water and Aquarel Sachet water, for the provision of the water samples used for this study.

\section{Conflicts of Interest}

The authors declare no conflict of interest.

\section{References}

1. Augustine, I.A., Ogbonnaya, E., Olaide, O.A., Emmanuel, O.O. and Uloaku O. Assessment of Sachet and Bottled Water Quality in Ibadan, Nigeria. Glob J. Nutr. Food Sci 2019, 1, 1-12, https://doi.org/10.33552/GJNFS.2019.01.000519.

2. Ndinwa, C.C.G., Chukumah, O.C., Edafe, E.A., Obarakpor, K.I., Morka, W.and Osubor-Ndinwa, P.N. Physicochemical and biological characteristics of bottled and sachet water in Warri and Abraka, Southern Nigeria J.Environ. Mgt Saf 2012, 3: 145 -160.

3. Fella, H. and Mohamed, B.E. Water quality and physicochemical parameters of outgoing waters in a pharmaceutical plant. App Wat Sci 2019, 9, 165, https://doi.org/10.1007/s13201-019-1046-1.

4. Yusuf, Y.O., Jimoh, A.I., Onaolapo. E.O. and Dabo, Y. An assessment of sachet water quality in Zaria Area of Kaduna State, Nigeria. J. Geo Reg Plan 2015, 8, 174-180, https://doi.org/10.5897/JGRP2015.0501.

5. Fisher, M.B., Williams, A.R., Jalloh, M.F., Saquee, G., Bain, R.E.S. and Bartram, J.K. Microbiological and chemical quality of packaged sachet water and household stored drinking water in freetown, Sierra Leone. PLOS ONE 2015, 10, 131-137, https://doi.org/10.1371/journal.pone.0131772.

6. Igbeneghu, O.A. and Lamikanra, A. The bacteriological quality of different brands of bottled water available to consumers in Ile-Ife, south-western Nigeria. BMC Res. Not. 2014, 7, 859, https://doi.org/10.1186/17560500-7-859. 
7. Ajala, O. J., Ighalo J.O., Adeniyi A.G., Ogunniyi S., Adeyanju C.A. Contamination issues in sachet and bottled water in Nigeria: a mini-review. Sustain. Water Resour. Manag. 2020, 6:112. https://doi.org/10.1007/s40899-020-00478-5

8. Folorunso F.A, Folorunso A.S, Oyebamiji A.K and Akintelu S.A Quality assessment of some bottled water produced in Okitipupa, Ondo state, Nigeria. Fr Ukr J Chem 2020, 8, 108-116. https://doi.org/10.17721/fujcV8I1P108-116.

9. Stoler, J., Weeks, J.R. and Fink, G. Sachet drinking water in Ghana's Accra-Tema metropolitan area: Past, present, and future. J Water Sanit Hyg Dev. 2012, 1, 223-240, https://doi.org/10.2166/washdev.2012.104.

10. Alhassan, M.M. and Ujoh, F. 2012. Assessment of the Chemical Quality of Potable Water Sources in Abuja, Nigeria. Brit J App Sci Techn 2012, 2, 146-172.

11. NAFDAC. 2009. National Agency for Food Drug Administration and Control. Guidelines for Registration of food and water manufactured in Nigeria NAFDAC/RR/ 005/00, 2009. Available online: http://www.nafdac.gov.ng/index.php?option=com_docman\&Itemid=103;2009 (accessed on 17 February 2019)

12. Emre, B., Cem, O.E. and Zübeyir T. Physicochemical properties of both drinking and domestic waters in Corum. Int. J. Sci. Let. 2019, 1, $42-55$.

13. Uneke, B.I. Water Quality Analysis of Some Selected Samples of Sachet Water in Abakaliki Urban, Ebonyi State, Nigeria: Its Public Health Significance. AASCIT J Bio. 2015, 1, 10-14.

14. Pardeshi, B.M. Screening of physicochemical parameters of water samples from pune area, India. $J$ Emer Techn Inn Res 2019, 6, 63-69.

15. Sunday, O.O., Adewale, S.A. and Adeleke, W.O. Determination of Shelf Life of Selected Sachet Water in Ogbomoso, Oyo State Nigeria. FUOYE J Eng Techn 2016, 1, 127-131.

16. Yumin, W., Ran, Y. and Guangcan, Z. Evaluation of Physicochemical Characteristics in DrinkingWater Sources Emphasized on Fluoride: A Case Study of Yancheng, China. Int J Environ Res Public Health 2019, 10, 1-16, https://dx.doi.org/ doi:10.3390/ijerph16061030.

17. Peter, C., Victor, N., Eltony, M., Tumo, K. and Noel, V.T.C. Situational analysis of physico-chemical, biochemical and microbiological quality of water along Mohokare River, Lesotho. Egypt. J Aqu Res 2019, 45, 45-51, https://doi.org/10.1016/j.ejar.2018.12.002.

18. Mustapha, D.I., Musa, U. and Akindele, A.A. Qualitative Assessment of Sachet and Bottled Water Marketed in Bauchi Metropolis, Nigeria. Chem Pro Eng Res 2015, 37, 11-23.

19. Taiwo, A.M, Gbadebo, A.M. and Awomeso, J.A. Potability Assessment of Selected Brands of Bottled Water in Abeokuta, Nigeria. J App Sci Environ Manage 2010, 14, 47-52.

20. W.H.O. 2008. Guidelines for drinking water quality, Geneva WHO 2008 www.lentech.com/WHO-drinkingwaterstandards06.htm (accessed on 17 February 2019).

21. Oyelude, E. O. and Ahenkorah, S. Quality of Sachet Water and Bottled Water in Bolgatanga Municipality of Ghana. Res J App Sci Eng Techn 2012, 4, 1094-1098.

22. S.O.N Nigerian Standard for Drinking Water Quality. Abuja, Nigeria: SON Publishing Company, 2007, 1533.

23. David, M., Elizabeth, T. and Sara, J.M. Informally vended sachet water: handling practices and microbial water quality. Water 2019, 11, 800; https://doi.org/10.3390/w11040800.

24. Mosi. L., Adadey, S.M., Sowah, S.A. and Yeboah, C. Microbiological assessment of sachet water "pure water" from five regions in Ghana [version 2; referees: 2 approved with reservations] AAS Open Res 2018, 1, 12, https://doi.org/10.12688/aasopenres.12837.2.

25. Muazu, J., Muhammad-Biu, A. and Mohammed, G.T. Microbial quality of packaged sachet water marketed in Maiduguri metropolis, North-Eastern Nigeria. Brit J Pharm Toxi 2012, 3, 33-8.

26. Stoler, J., Tutu, R.A., Ahmed, H., Frimpong, L.A. and Bello, M. Sachet water quality and brand reputation in two low-income urban communities in greater Accra, Ghana. Am. J. Trop. Med. Hyg 2014, 90, 272-278, https://doi.org/10.4269/ajtmh.13-0461.

27. Akpen, G.D., Kpoghol, I.S. and Oparaku, L. A. Quality Assessment of Sachet and Bottled Water Soldin Gboko, Benue State, Nigeria. Nig J Techn 2018, 1, 241-248, https://doi.org/10.4314/njt.v37i1.32.

28. Danso-Boateng, E. and Frimpong, I.K. Quality Analysis of Plastic Sachet and Bottled Water Brands Produced or sold in Kumasi, Ghana. Int J Dev Sus 2013, 2, 2222-2232. 